\title{
In vitro morphogenesis and cell suspension culture establishment in Piper solmsianum C. DC. (Piperaceae)
}

\author{
Tiago Santana Balbuena ${ }^{1}$, Claudete Santa-Catarina ${ }^{1}$, Vanildo Silveira ${ }^{2}$, Massuo Jorge Kato $^{3}$ and \\ Eny Iochevet Segal Floh ${ }^{1,4}$
}

Received: March 3, 2008. Accepted: August 11, 2008

\begin{abstract}
RESUMO - (Morfogênese in vitro e estabelecimento de culturas de suspensão celular em Piper solmsianum C. DC. (Piperaceae)). Piper solmsianum é uma espécie herbácea do sudeste brasileiro onde vários compostos biologicamente ativos já foram identificados. O objetivo deste trabalho foi estabelecer suspensões celulares nesta espécie. Para tanto, foram utilizados explantes de pecíolos e folhas, retirados de plântulas cultivadas in vitro, os quais foram submetidos a diferentes combinações de reguladores de crescimento (AIA, ANA, 2,4-D e BAP). Foi obtida a neo-formação de raízes e brotos, estes últimos através do processo de organogênese indireta evidenciada por estudos histológicos. Para a indução e crescimento dos calos, foram avaliados, além das diferentes combinações de reguladores de crescimento, a suplementação ao meio de cultura de carvão ativado $\left(1,5 \mathrm{mg} \cdot \mathrm{l}^{-1}\right)$ e o regime de luz. Culturas mantidas na luz, em meio de cultura suplementado com 0,2 mg.1 $1^{-1}$ 2,4-D e 2 mg. $1^{-1}$ BAP e sem carvão ativado, resultaram em maior crescimento (massa fresca) dos calos. A partir destes calos, foram obtidas suspensões celulares, cuja dinâmica de crescimento e acúmulo de metabólitos foi estudado. Os resultados obtidos deverão ser utilizados para a caracterização de rotas biosintéticas em culturas in vitro em P. solmsianum.
\end{abstract}

Palavras-chave: calogênese, morfogênese, pariparoba, reguladores de crescimento, suspensões celulares

\begin{abstract}
In vitro morphogenesis and cell suspension culture establishment in Piper solmsianum C. DC. (Piperaceae)). Piper solmsianum is a shrub from Southeast Brazil in which many biologically active compounds were identified. The aim of this work was to establish a cell suspension culture system for this species. With this in mind, petiole and leaf explants obtained from in vitro plantlets were cultured in the presence of different plant growth regulator combinations (IAA, NAA, 2,4-D and BA). Root and indirect shoot adventitious formation, detected by histological analysis, was observed. Besides the different combinations of plant growth regulators, light regime and the supplement of activated charcoal $\left(1.5 \mathrm{mg} \cdot \mathrm{l}^{-1}\right)$ were tested for callus induction and growth. Cultures maintained in light, on a $0.2 \mathrm{mg} . \mathrm{l}^{-1}$ 2,4-D and $2 \mathrm{mg} . \mathrm{l}^{-1} \mathrm{BA}$ supplemented medium, and in the absence of activated charcoal, showed the highest calli fresh matter increment. From a callus culture, cell suspension cultures were established and their growth and metabolite accumulation studied. The achieved results may be useful for further characterization of the activated secondary metabolites pathways in in vitro systems of P. solmsianum.
\end{abstract}

Key words: callogenesis, cell suspension culture, morphogenesis, pariparoba, plant growth regulators

\section{Introduction}

The Piperaceae family comprises 14 genera and ca. 1,950 species, of which the genus Piper is the largest, with more than 600 species described worldwide (Danelutte et al. 2003). Besides being of high commercial and economical importance, Piper species are medicinally used in different ways, such as in the Indian Ayurvedic system of medicine and in the folklore medicine of Latin America and the West Indies (Parmar et al. 1997). Piper species produce many biologically active compounds, including amides, flavanones, alkaloids, propenylphenols, lignans, neolignans, benzoic acids and chromenes (Parmar et al. 1997; 1998; Navickiene et al. 2003; Silva et al. 2002; Danelutte et al. 2003; Martins et al. 2003; Lago et al. 2004).

Piper solmsianum is a shrub measuring 1-3 meters tall, commonly found in Southern Brazil. Phytochemical studies revealed the presence of monoterpenes, sesquiterpenes, arylpropanoids, phenylpropanoids, lignans and neolignans, most of which showing biological activity against bacteria, fungus and the trypomastigote form of Trypanossoma cruzi (Moreira et al. 1995; Martins et al. 2000; 2003; Campos et al. 2005; 2007).

1 Universidade de São Paulo, Instituto de Biociências, Departamento de Botânica, Rua do Matão 277, 05422-970 São Paulo, SP, Brasil

2 Universidade Estadual do Norte Fluminense, Centro de Biociências e Biotecnologia, Av. Alberto Lamego 2000, 28013-60 Campos dos Goytacazes, RJ, Brasil

3 Universidade de São Paulo, Instituto de Química, Departmento de Química Fundamental, Av. Professor Lineu Prestes 748, 05508-000 São Paulo, SP, Brasil

4 Corresponding author: enyfloh@usp.br 
In vitro propagation of medicinal plant species has the advantage of compound production under controlled conditions, which means that cells of any plant can be easily multiplied to yield their specific metabolites (Vanisree et al. 2004). Some Piper cultures have already been established and their morphogenetic potential investigated, such as for Piper longum (Bhat et al. 1992; 1995; Soniya \& Das 2002), Piper nigrum (Mathews \& Rao 1984; Phillip et al. 1992), Piper colubrinum (Kelkar \& Krishnamurthy 1998) and Piper methysticum (Briskin et al. 2001; Smith et al. 2002). High-frequency regeneration through somatic embryogenesis was achieved for $P$. nigrum and $P$. colubrinum (Joseph et al. 1996; Yusuf et al. 2001; Nair \& Gupta 2006).

Plant cell cultures have been actively studied as a potential source of high-value biological compounds (Edahiro \& Seki 2006). The major advantages of a cell culture system over the conventional cultivation of whole plants are: useful compounds can be produced under controlled conditions independent of climatic changes or soil conditions; cultured cells would be free of microbes and insects; the cells of any plants could easily be multiplied to yield their specific metabolites; automated control of cell growth and rational regulation of metabolite processes would reduce of labor costs and improve productivity (Vanisree et al. 2004). Establishment of cell suspension cultures capable of producing medicinal compounds at a rate similar or higher than intact plants have accelerated over the last few years, mostly due to optimization of the cultural conditions, selection of high-producing strains and employment of precursor feeding, transformation methods and immobilization techniques (Vanisree et al. 2004).

Besides the use for large-scale metabolite production, cell suspension culture technique may be employed for studying important biosynthetic pathways. In order to obtain high yields suitable for commercial exploitation, efforts have focused on studying the biosynthetic pathways of biologically active compounds through cell suspension culture (Dicosmo \& Misawa 1995). Recently, Danelutte et al. (2005) carried out the only study aimed at establishing cell suspension cultures in Piperaceae and an investigation of the associated secondary metabolites in Piper cernuum and Piper crassinervium.

Although the recent findings on the vast quantity of biologically active compounds accumulated in P. solmsianum plants, there are no reports on in vitro propagation of this species. Thus, the aim of this study was to establish cell suspension cultures for further investigation on the biosynthesis of secondary metabolites in batch systems for this species.

\section{Materials and methods}

Establishment of aseptic cultures - Seeds of Piper solmsianum C.DC. were collected from the Parque Estadual da Serra do Mar, Ubatuba, Brazil. Seeds were surface sterilized in a solution of $1 \%$ sodium hypochlorite plus one drop of detergent for $20 \mathrm{~min}$, followed by $30 \mathrm{~s}$ immersion in $70 \%$ ethanol. The material was rinsed five times with sterile, distilled water in a clear air cabinet, three to five surface-sterilized seeds were placed into test tubes containing culture medium.

Media and culture conditions - All cultures were maintained in a culture growth-room at $26^{\circ} \mathrm{C}$, under a photosynthetic photon flux of $35 \mu \mathrm{mol} . \mathrm{m}^{-2} . \mathrm{s}^{-1}$ provided by cool white fluorescent tubes and photoperiod of $16 \mathrm{~h}$. The materials grown in the dark were cultured in the same growth-room at $26^{\circ} \mathrm{C}$. A MS (Murashige \& Skoog 1962) basal culture medium, supplemented with $30{\mathrm{~g} . l^{-1}}^{-1}$ of sucrose and $2 \mathrm{~g}^{-1} \mathrm{l}^{-1}$ of Phytagel (Sigma ${ }^{\circledR}$ ), was used in all the steps described herein. The $\mathrm{pH}$ was adjusted to 5.7 prior to autoclaving at $121{ }^{\circ} \mathrm{C}$ for $20 \mathrm{~min}$.

Plantlet mass propagation - Prior to the study of $P$. solmsianum morphogenesis, in vitro mass propagation was carried out through axillary bud propagation. First and second axillary buds emerging from germinated plantlets were excised, vertically placed onto the basal hormone-free media and sub-cultured after 45 days of growth. This strategy permitted both obtaining large quantities and achieving a synchronized growth of the plantlet culture for the study of morphogenetic responses in this species.

Morphogenetic potential study - The two youngest leaves $(10 \mathrm{~mm}$ of diameter) and petioles $(10 \mathrm{~mm})$ were excised from 45 days old in vitro grown plantlets. Petiole and leaf explants were horizontally placed onto the culture medium. Leaf discs were placed with the abaxial side in contact with the culture medium. In order to investigate P. solmsianum morphogenetic potential, explants were cultured in a basal medium containing different combinations ( $\left(0,0.2\right.$ and $\left.2 \mathrm{mg}^{-1} \mathrm{l}^{-1}\right)$ of the auxins 3-indolylacetic acid (IAA), 1-naphthalene acetic acid (NAA), 2,4-dichlorophenoxyacetic acid (2,4-D) and the cytokinin 6-benzylaminopurine (BA). In each treatment 10 repetitions with 5 explants for each experimental unit were tested. Explants were cultivated in the $16 \mathrm{~h}$ photoperiod condition for 30 days, and then analyzed by observing achieved morphogenetic responses.

Histological analysis - Explants from treatments that resulted in shoot differentiation from the morphogenetic potential study, were fixed in $0.2 \mathrm{M}$ phosphate buffer: $2.5 \%$ paraformaldehyde solution (1:1) for $24 \mathrm{~h}$. Material 
was washed in phosphate buffer for $30 \mathrm{~min}$ and dehydrated by passing through a graded series of ethanol. Infiltration was carried out with ethanol: historesin $\left(\right.$ Leica $\left.^{\circledR}\right)(1: 1)$ for $24 \mathrm{~h}$, followed by $100 \%$ historesin for 2-3 h. Serial sections of $6 \mu \mathrm{m}$ were cut and stained with $0.5 \%$ toluidine blue $\mathrm{O}$ in $50 \%$ ethanol for $1 \mathrm{~min}$, and then examined under a light microscope.

Establishment of callus and cell suspension cultures For the establishment and optimization of callus culture conditions, petioles were inoculated into test tubes containing the MS basal medium and treatments that induced callogenesis. In each treatment 10 repetitions with 5 explants for each experimental unit were tested. The effect of light/dark regime, activated charcoal (1.5 mg. $\left.\mathrm{l}^{-1}\right)$ supplement and growth regulator (2,4-D and BA) were analyzed through fresh matter (FM) increment after 30 days of culture. Data were analyzed by ANOVA and means were submitted to a 5\% significance StudentNewman-Keuls (SNK) test. Cell suspension cultures were initiated by culturing callus in Erlenmeyer flasks containing the callus-optimized culture medium without Phytagel $\left(\right.$ Sigma $\left.^{\circledR}\right)$. Sedimented cell volume (SCV) and dry matter were determined during a culture cycle (42 days), in order to analyze both cell suspension and callus growth, respectively. Mean and standard error were applied to analyze the data.

Metabolite extraction in suspension cultures - Cells were isolated from culture medium (15 flasks), using $0.2 \mu \mathrm{m}$ cellulose acetate filters $\left(\right.$ Sartorius $^{\circledR}$ ), after 15 and 40 days of culture and stored at $-80{ }^{\circ} \mathrm{C}$ prior to extraction. The lyophilized cells $(200 \mathrm{mg}$ ) were ground to a fine powder under liquid nitrogen and then metabolites were extracted using a dichloromethane: methanol (2:1) solution for $30 \mathrm{~min}$. Extract was concentrated on rotoevaporator. Metabolites in the culture medium $(750 \mathrm{ml})$ were threetimes extracted in ethyl acetate and then solvent was removed under vacuum using a rotoevaporator. Crude extracts were passed through reversed-phase Sep-Pak C18 cartridges prior to HPLC analysis.

HPLC analysis - Aliquots ( $20 \mu \mathrm{l})$ of stored samples were analyzed by HPLC using a $5 \mu \mathrm{m}$ reverse phase column $\left(\right.$ Supelcosil C18, Supelco ${ }^{\circledR}$ ). Mobile phase was constituted of acetonitrile in water and the gradient of acetonitrile was programmed to $30 \%$ over the first $8 \mathrm{~min}$, from $30 \%$ to $100 \%$ between 8 and 35 min and 100\% between 35

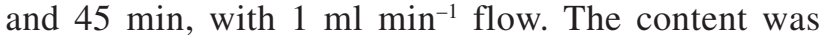
determined using a ultra-violet/visible detector at $254 \mathrm{~nm}$.

\section{Results and discussion}

Germination of Piper solmsianum achieved approximately 35 and $80 \%$ after 4 and 8 weeks of culture, respectively. The establishment of Piper cultures is frequently slow and difficult. Fungal and bacteria contamination usually hampers culture establishment (Phillip et al. 1992; Bhat et al. 1995; Kelkar \& Krishnamurthy 1998). However, in P. solmsianum only $10 \%$ of the inoculated seeds showed pathogen contamination. Axillary bud-mass propagation in a hormone-free MS basal medium resulted in plantlet formation, one plantlet for each axillary bud inoculum, and allowed for obtaining high quantities of plantlets to be used in morphogenesis investigation.

The morphogenetic potential of $P$. solmsianum in an MS basal medium supplemented with different concentrations of IAA, NAA, 2,4-D and BA, is summarized in Tab. 1. Petiole explants were the most responsive and besides callus formation, shoot organogenesis and rhizogenesis were also observed (Fig. 1).

Table 1. Responses of Piper solmsianum C. DC. explants to combinations of BA with IAA, NAA or 2,4-D after 30 days of culture. $\mathrm{N}=$ no response; $\mathrm{R}=$ root formation, $\mathrm{S}=$ shoot formation, $\mathrm{C}=$ callus formation; +++ more than 15 buds per explant; ++ 6-14 buds per explant; + 1-5 buds per explant.

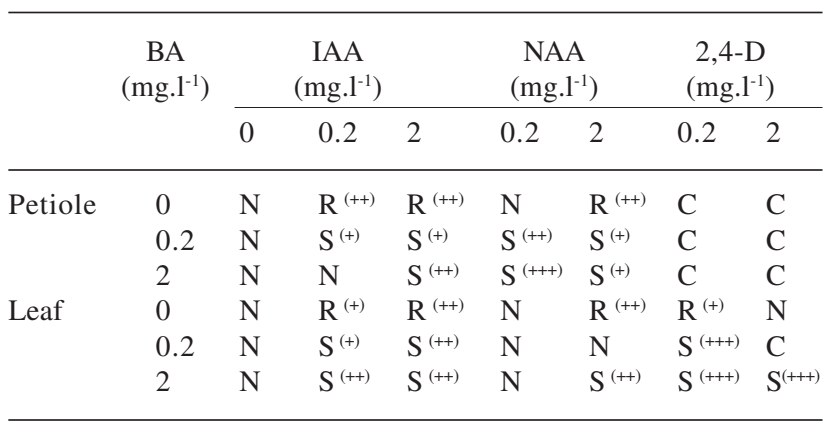

Root formation was observed only in the absence of BA. IAA treatments resulted in rhizogenesis in both 0.2 and $2 \mathrm{mg} \cdot \mathrm{l}^{-1}$ concentrations, whereas in NAA treatments, this morphogenetic response was only observed in the $2 \mathrm{mg} \cdot \mathrm{l}^{-1}$ concentration (Tab. 1). Media supplemented with the synthetic auxin $2,4-\mathrm{D}$ were inefficient for root formation. Only leaf explants treated with $0.2 \mathrm{mg} . \mathrm{l}^{-1} 2,4-\mathrm{D}$ resulted in rhizogenesis.

Shoot organogenesis was the most frequently observed morphogenetic response (Tab. 1). Bhat et al. (1995) observed high regeneration rates using different explants in P. longum, P. betle and P. nigrum. After thirty days of culture, shoot organogenesis was observed in thirty-eight percent of the treatments. The application of both auxin and cytokinin regulators was essential for this response. In P. solmsianum, BA was essential for shoot induction, although this regulator is not essential for other Piper species (Mathews \& Rao 1984; Philip et al. 1992; Bhat et al. 1992; 1995; Aminuddin-Johri 

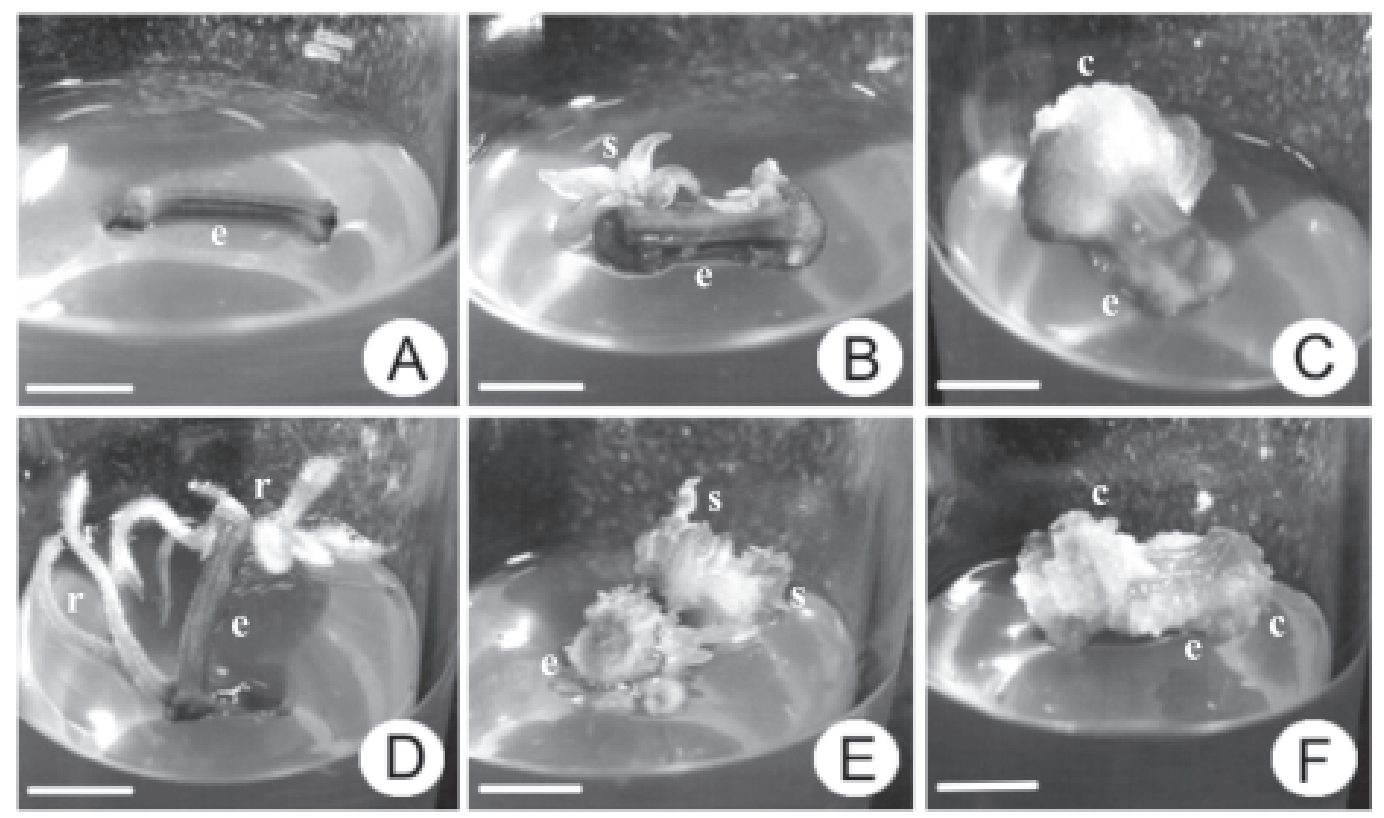

Figure 1. Responses of in vitro Piper solmsianum C. DC. petiole explants after 30 days of culture. A. Control. B. 2 mg. $1^{-1}$ BA and 2 mg..$^{-1}$ IAA. C. 2 mg..$^{-1}$ BA and 0.2 mg. $1^{-1}$ 2,4-D. D. 2 mg..$^{-1}$ IAA. E. 2 mg..$^{-1}$ BA and 0.2 mg. $.1^{-1}$ NAA. F. 0.2 mg. $.1^{-1}$ BA and 0.2 mg. $.^{-1} 2,4-D$. C, R, S - callus, root and shoot formation, respectively; $\mathrm{E}$ - petiole explant. Bars $=3.4 \mathrm{~cm}$.

et al. 1993; Kelkar et al. 1996; Kelkar \& Krishnamurthy 1998). In leaf explants, all IAA and BA combinations resulted in shoot organogenesis, whereas only $2 \mathrm{mg} \cdot \mathrm{l}^{-1}$ NAA plus $2 \mathrm{mg} .1^{-1} \mathrm{BA}$ treatments resulted in this morphogenetic response. In 2,4-D treatments, adventitious shoot formation was observed in $2 \mathrm{mg} \cdot \mathrm{l}^{-1}$ BA concentration treatments and in $0.2 \mathrm{mg} . \mathrm{l}^{-1} 2,4-\mathrm{D}$ plus $0.2 \mathrm{mg} . \mathrm{l}^{-1} \mathrm{BA}$ combinations. In petiole explants, shoot organogenesis was observed in all auxin and cytokinin combinations. Nevertheless, the synthetic auxin 2,4-D did not induce root or shoot regeneration in these explants.

Preferential regions of tissue differentiation were observed during $P$. solmsianum morphogenetic potential investigation (Fig. 1). In petioles, root adventitious formation at the cut end of the explant was very evident and is probably associated with the presence and distinct distribution of endogenous regulators. In $P$. longum this process was detected throughout vessels and in the proximal region of leaf explants (Soniya \& Das 2002; Kelkar \& Krishnamurthy 1998).

Histological analysis revealed that adventitious shoot formation was achieved through indirect organogenesis (Fig. 2A). The 30-day cultured leaf and petiole explants showed the formation of elongated, vacuolated and loosely arranged tissue, characteristic of friable calluses, at the end of the cut section (Fig. 2A-B). Cylindrical meristemoids were observed at the inner part of this tissue (Fig. 2A-B), while the outer cells of calluses underwent division, leading to the formation of densely cytoplasmatic isodiametric cells with pro-eminent and enlarged nuclei (Fig. 2B-C). Notch-like structures were formed in these meristematic regions, as has been described for $P$. longum indirect shoot-formation (Bhat et al. 1995), which subsequently resulted in the formation of shoot buds (Fig. 2C). Leaf primordia were also seen around the developing shoot- apex (Fig. 2D).

In plants, both auxins and cytokinins are necessary for cell transition from $\mathrm{G} 1$ to $\mathrm{S}$ cell cycle phase and from G2 to M cell cycle phase (Stals \& Inzé 2001). In $P$. solmsianum, callus formation was observed in all petiole explants treated with 2,4-D. However, in leafexplants a small brown callus was only observed in the $0.2 \mathrm{mg} . \mathrm{l}^{-1} \mathrm{BA}$ plus $2 \mathrm{mg} . \mathrm{l}^{-1}$ 2,4-D treatments, suggesting differences in sensitivity between the explants used. In order to obtain white, friable, fast growing calluses, the light/dark regime and supplementation with activated charcoal were studied for callus formation from petiole explants, together with the different combinations of growth regulators that induced callogenesis. Light-effect is one of the most important factors in plant morphogenesis (Morini et al. 2000). In P. solmsianum, light-grown materials revealed FM increment than did that from the dark condition (Fig. 4). Rapid medium and explant browning is common during the establishment of Piper cultures, and is mainly due to the presence of phenolics that under oxidation produce growth inhibitor polyphenols and quinones 

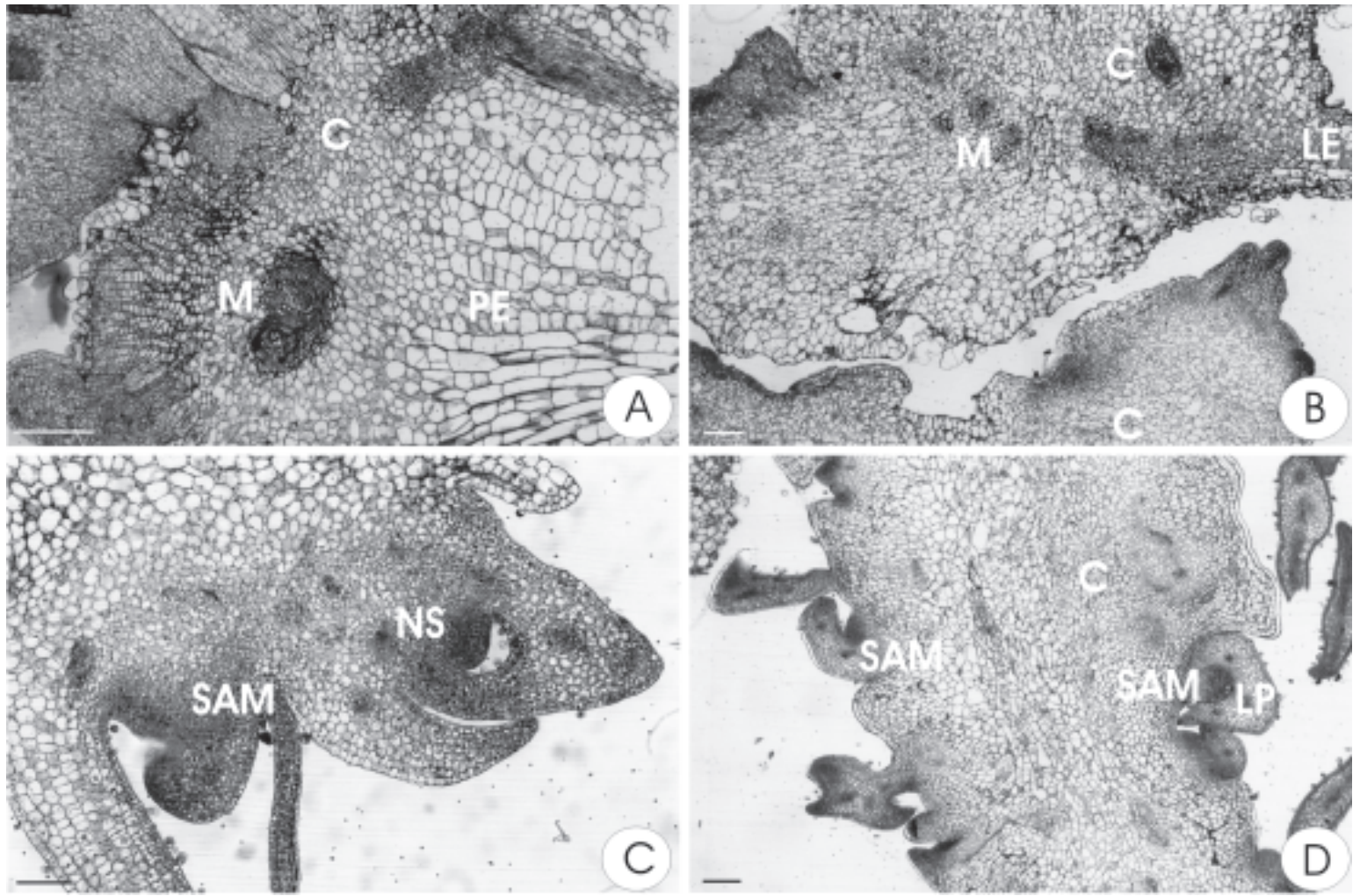

Figure 2. Histological analysis of Piper solmsianum C. DC. in vitro shoot regeneration. A-B. Callus formation from the cut end of petiole and leaf explants (M - cylindrical meristemoids, C - callus, PE - petiole explant, LE - leaf explant). C-D. Shoot regeneration by differentiation from the outer layer of callus cells (SAM - shoot apical meristem, NS - notch-like structure which will differentiate into shoot buds, LP - leaf primordia). Bars $=50 \mu \mathrm{m}$.

(Madhusudhanan \& Rahiman 2000). Activated charcoal can adsorb inhibitory compounds secreted from plant tissues, and thus reduce their effect (Teixeira et al. 1994). In order to control polyphenol leaching, activated charcoal was supplemented into the culture medium. In general, although reducing the browning effect (data not shown), the supplementation of activated charcoal inhibited callus growth (Fig. 4). It is known that activated charcoal can absorb growth regulators, limiting their use in the culture, and consequently affecting both tissue growth and morphogenesis (Ebert \& Taylor 1990). Among growth-regulator treatments, $0.2 \mathrm{mg} . \mathrm{l}^{-1}$ 2,4-D plus $2 \mathrm{mg} \cdot \mathrm{l}^{-1} \mathrm{BA}$ combination resulted in the highest MF increment (Fig. 4).

Optimized culture conditions ( $16 \mathrm{~h}$ photoperiod and supplementation with $0.2 \mathrm{mg} .1^{-1} 2,4-\mathrm{D}$ plus $2 \mathrm{mg} .1^{-1} \mathrm{BA}$ ) were used for callus growth and investigation of cell suspension growth dynamics during a culture cycle. The $P$. solmsianum callus lag-phase was extensive during approximately 20 days. The exponential phase could not be well delimited. However, the stationary phase was reached at day 36 of culture (Fig. 3A). Cell suspension cultures, induced by callus cells at day 24 of culture, showed an increase in SCV from $0.6 \mathrm{ml}$ to $2 \mathrm{ml}$ after 42 days of culture, without subculture (Fig. 3B). The lag-
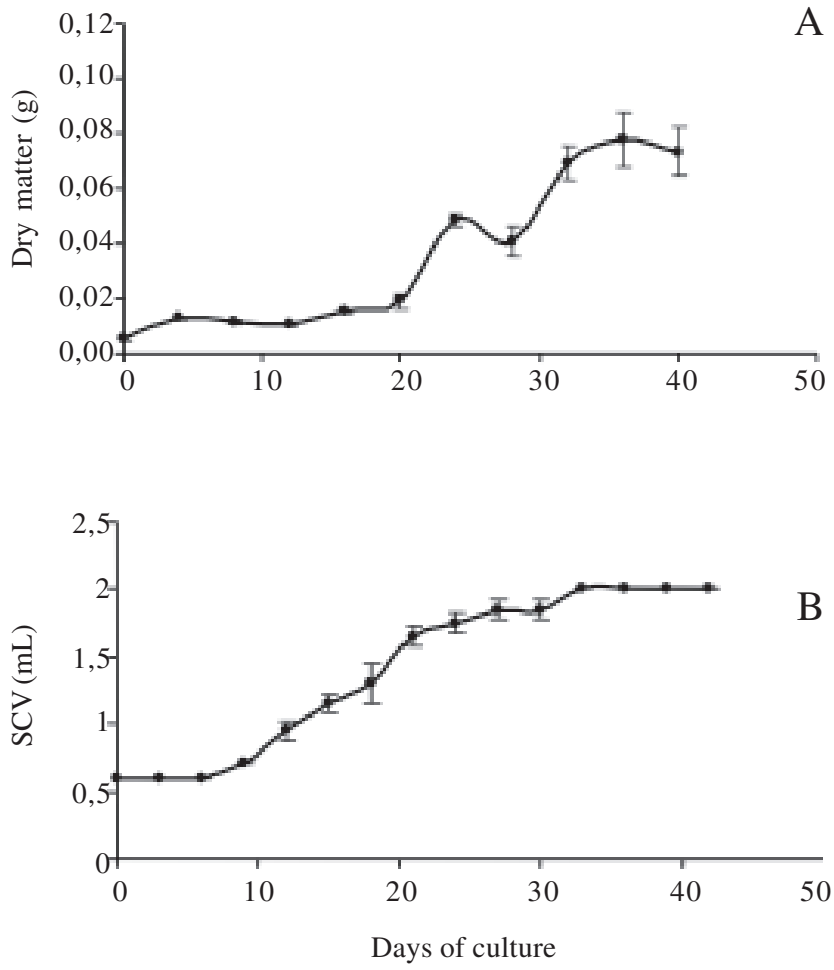

Figure 3. Piper solmsianum C. DC. callus (A) and cell suspension growth (B) during 40 and 42 days of culture, respectively. SVC - sedimented cell volume. 
phase lasted only 6 days, followed by a 12-day exponential phase, when the growth-rate increased $10 \%$ per day. The stationary phase was reached at day 30 of

$$
\text { Light }
$$
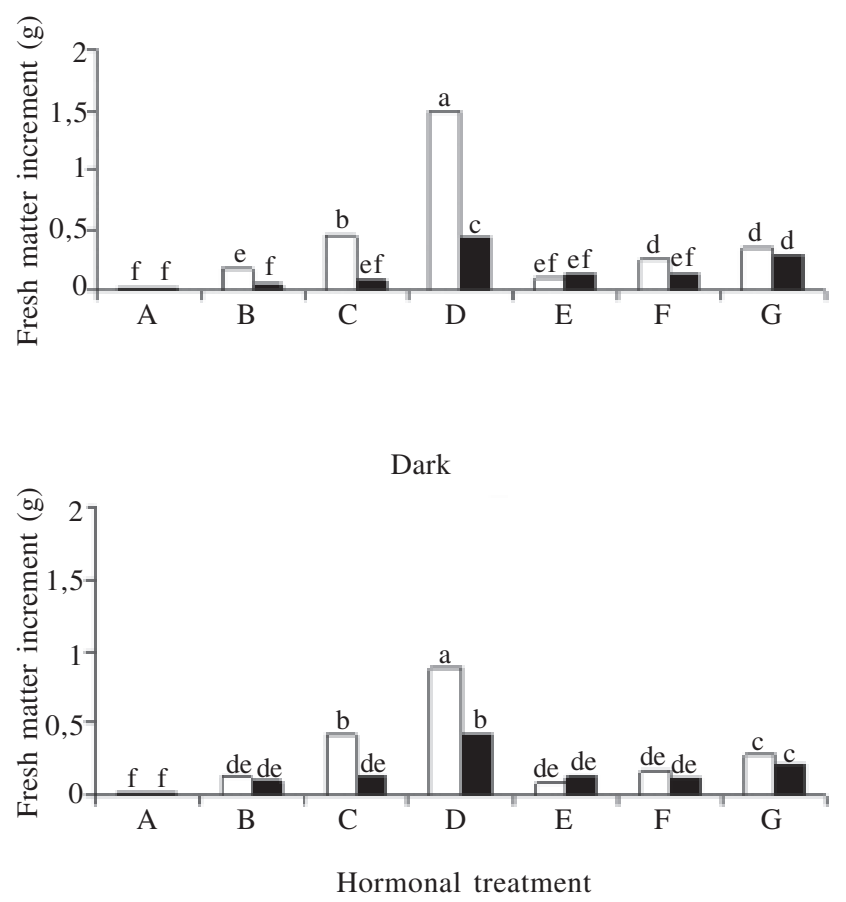

Figure 4. Piper solmsianum C. DC. callus fresh matter increment (g) after 30 days of culture in different conditions. Hormonal treatments: A - control; B - 0.2 mg. $.^{-1} 2,4-\mathrm{D}$; C - $0.2 \mathrm{mg} . \mathrm{l}^{-1} 2,4-\mathrm{D}+0.2 \mathrm{mg} . \mathrm{l}^{-1} \mathrm{BA}$; D - $0.2 \mathrm{mg} . \mathrm{l}^{-1} 2,4-\mathrm{D}+2 \mathrm{mg} . \mathrm{l}^{-1} \mathrm{BA} ; \mathrm{E}-2 \mathrm{mg} . \mathrm{l}^{-1} 2,4-\mathrm{D} ; \mathrm{F}-2 \mathrm{mg} . \mathrm{l}^{-1}$ 2,4-D+0.2 mg..$^{-1}$ BA; G - 2 mg. $.^{-1} 2,4-D+2$ mg..$^{-1}$ BA. ( $\square=$ no activated charcoal; $\mathbf{\square}=$ activated charcoal).
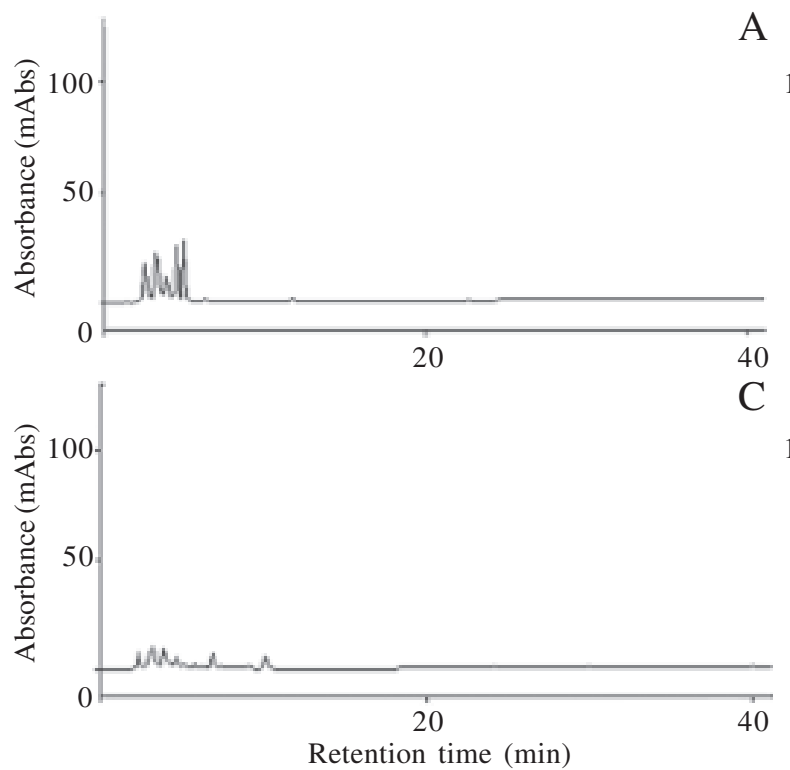

A culture. In a suspension culture with a finite mediumvolume, an S-shaped growth-curve is generally observed as the start inoculum passes through a series of characteristic growth phases initiated by a lag phase, a period of cell adaptation into the new culture medium, followed by a high rate of cell division, the exponential phase, and then a linear growth phase. The rate of cell growth is reduced during the stationary growth-phase (Szabados et al. 1993)

Although cells in the suspension culture are undifferentiated, some may be induced to start a differentiation process during the period of slowed and stationary growth (George 1993). Generally, only a small amount of secondary metabolites is being produced at the exponential phase of growth, as nutrients and common precursors are being allocated to primary metabolism, this resulting in biomass increment (Bourgaud et al. 2001). When there is a reduction in growth rates and cells start to differentiate, plant cell metabolism is shifted to the biosynthesis of secondary metabolites, thus indicating biochemical differentiation and consequent activation of those enzymes responsible for secondary metabolite production (Payne et al. 1991; Bourgaud et al. 2001). In $P$. solmsianum cell suspension culture a vast quantity of metabolites were detected in the culture medium, suggesting that cells are capable of excreting metabolites into the medium (Fig. 5). As predicted, extracts from the culture medium at the stationary phase ( 40 days of culture) showed the highest variety of accumulated compounds. This is an attractive feature for large scale production, as compounds can be easily recovered from
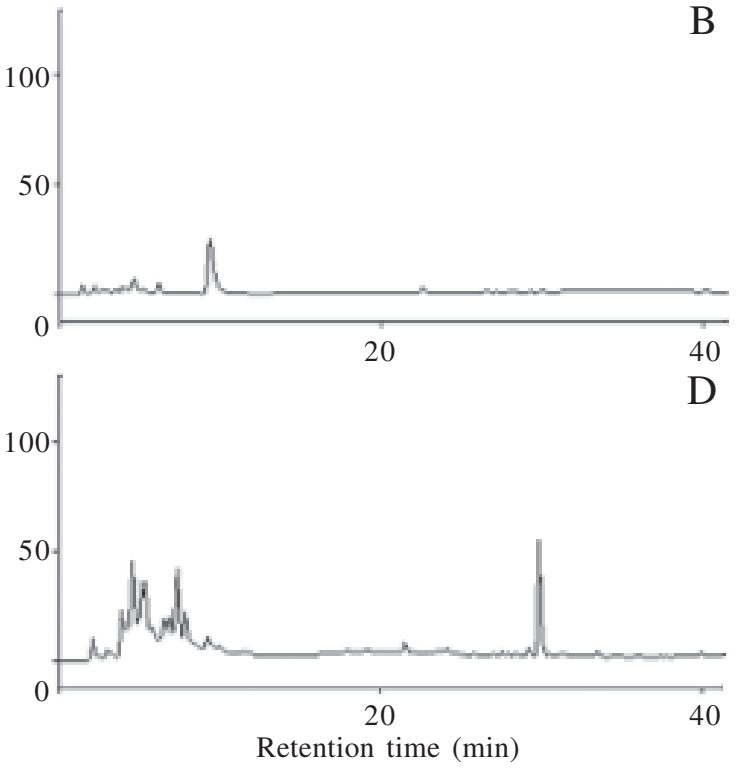

Figure 5. Chromatograms of Piper solmsianum C. DC. cell suspension cultures during 45 days of culture: A. Cells at the exponential phase (15 days). B. Culture medium at the exponential phase (15 days). C. Cells at stationary phase (40 days). D. Culture medium extract at the stationary phase (15 days). 
the suspension culture without interfering with cell growth.

P. solmsianum proved to be highly amenable to cell-culture techniques. The identification of secondary metabolites accumulated in cell suspension culture may provide important information for characterization and studying phenolic metabolites biosynthesis, especially of those related to the phenylpropanoids and lignan pathway.

\section{Acknowledgements}

This research was carried out with financial support from the National Council for Scientific and Technological Development (CNPq) and the State of São Paulo Research Foundation (FAPESP).

\section{References}

Aminuddin-Johri, J.K.; Anis, M. \& Balasubrahmanyam, V.R. 1993. Regeneration of Piper betle from callus tissue. Current Science 65: 793-796.

Bhat, S.R.; Kackar, A. \& Chandel, K.P.S. 1992. Plant regeneration from callus cultures of Piper longum L. by organogenesis. Plant Cell Reports 11: 525-528.

Bhat, S.R.; Chandel, K.P.S. \& Malik, S.K. 1995. Plant regeneration from various explants of cultivated Piper species. Plant Cell Reports 14: 398-402.

Bourgaud, F.; Gravot, A.; Milesi, S. \& Gontier, E. 2001. Production of plant secondary metabolites: a historical perspective. Plant Science 161: 839-851.

Briskin, D.P.; Kobayashi, H.; Mehta, A.; Gawienowski, M.C.; Ainsworth, L. \& Smith, M.A.L. 2001. Production of kavapyrones by Kava (Piper methysticum) tissue cultures. Plant Cell Reports 20: 556-561.

Campos, M.P.; Filho, V.C.; Silva, R.Z.; Yunes, R.A.; Zacchino, S.; Juarez, S.; Cruz, R.C.B. \& Cruz, A.B. 2005. Evaluation of antigungal activity of Piper solmsianum C. DC. var. solmsianum (Piperaceae). Biological and Pharmaceutical Bulletin 28: 1527-1530.

Campos, M.P.; Filho, V.C.; Silva, R.Z.; Yunes, R.A.; Monache, F.D. \& Cruz, A.B. 2007. Antibacterial activity of extract, fractions and four compounds extracted from Piper solmsianum C.DC. var. solmsianum (Piperaceae). Zeitschrift für Naturforschung 62: 173-178.

Danelutte, A.P.; Lago, J.H.G.; Young, M.C.M. \& Kato, M.J. 2003. Antifungal flavanones and prenylated hydroquinones from Piper crassinervium Kunth. Phytochemistry 64: 555-559.

Danelutte, A.P.; Constantin, M.B.; Delgado, G.E.; Braz Filho, R. \& Kato, M.J. 2005. Divergence of secondary metabolism in cell suspension cultures and differentiated plants of Piper cernuum and Piper crassinervium. Journal of the Brazilian Chemical Society 16: 1425-1430.

Dicosmo, F. \& Misawa, M. 1995. Plant cell and tissue culture: alternatives for metabolite production. Biological Advances 13: 425-453.
Ebert, A. \& Taylor, H.F. 1990. Assessment of changes of 2,4dichlorophenoxyacetic acid concentrations in plant tissue culture media in the presence of activated charcoal. Plant Cell, Tissue and Organ Culture 20: 165-172.

Edahiro, J-I. \& Seki, M. 2006. Phenylpropanoid metabolite supports cell aggregate formation in strawberry cell suspension culture. Journal of Bioscience and Bioengineering 102: 8-13.

George, E.F. 1993. Plant tissue culture techniques. Pp. 3-36. In: E.F. George (ed.). Plant Propagation by Tissue Culture. Edington, Exegetics Limited.

Joseph, B.; Joseph, D.; Philip, V.J. 1996. Plant regeneration from somatic embryos in black pepper. Plant Cell, Tissue and Organ Culture 47: 87-90.

Kelkar, S.M.; Deboo, G.B. \& Krishnamurthy, K.V. 1996. In vitro plant regeneration from leaf callus in Piper colubrinum Link. Plant Cell Reports 16: 215-218.

Kelkar, S.M. \& Krishnamurthy, K.V. 1998. Adventitious shoot regeneration from root, internode, petiole and leaf explants of Piper colubrinum Link. Plant Cell Reports 17: 721-725.

Lago, J.H.G.; Ramos, C.S.; Casanova, D.C.C.; Morandim, A.A.; Bergamo, D.C.B.; Cavalheiro, A.J.; Bolzani, V.S.; Furlan, M.; Guimarães, E.F.; Young, M.C.M. \& Kato, M.J. 2004. Benzoic acid derivatives from Piper species and their fungitoxic activity against Cladosporium cladosporioides and $C$. sphaerospermum. Journal of Natural Products 67: 1783-1788.

Madhusudhanan, K. \& Rahiman, B.A. 2000. The effect of activated charcoal supplemented media to browning of in vitro cultures of Piper species. Biologia Plantarum 43: 297-299.

Martins, R.C.C.; Latorre, L.R.; Sartorelli, P. \& Kato, M.J. 2000. Phenylpropanoids and tetrahydrofuran lignans from Piper solmsianum. Phytochemistry 55: 843-846.

Martins, R.C.C.; Lago, J.H.C.; Albuquerque, S. \& Kato, M.J. 2003. Trypanocidal tetrahydrofuran lignans from inflorescences of Piper solmsianum. Phytochemistry 64: 667-670.

Mathews, V.H. \& Rao, P.S. 1984. In vitro responses of black pepper (Piper nigrum). Current Science 53: 183-186.

Moreira, D.L.; Guimarães, E.F.; Kaplan, M.A.C. 1995. Constituintes químicos de Piper solmsianum C.DC. (Piperaceae). Revista Brasileira de Farmacognosia 76: 106-109.

Morini, S.; D’Onofrio, C.; Bellocchi, G. \& Fisichella, M. 2000. Effect of 2,4-D and light quality on callus production and differentiation from in vitro quince leaves. Plant Cell, Tissue and Organ Culture 63: 47-55.

Murashige, T. \& Skoog, F. 1962. A revised medium for rapid growth and bio-assays with tobacco tissue cultures. Physiologia Plantarum 15: 473-497.

Nair, R.R. \& Gupta, S.D. 2006. High-frequency plant regeneration through cyclic secondary somatic embryogenesis in black pepper (Piper nigrum L.). Plant Cell Reports 24: 699-707.

Navickiene, H.M.D.; Bolzani, V.D.; Kato, M.J.; Pereira, A.M.S.; Bertoni, B.W.; Franca, S.C. \& Furlan, M. 2003. Quantitative determination of anti-fungal and inseticide amides in adult plants, plantlets and callus from Piper tuberculatum by reverse-phase high-performance liquid chromatography. Phytochemical Analyses 14: 281-284. 
Parmar, V.S.; Jain, S.C.; Bisht, K.S.; Jain, R.; Taneja, P.; Jha, A.; Tyagi, O.D.; Prasad, A.K.; Wengel, J.; Olsen, C.E. \& Boll, P.M. 1997. Phytochemistry of the genus Piper. Phytochemistry 46: 597-673.

Parmar, V.S.; Jain, S.C.; Gupta, S.; Talwar, S.; Rajwanshi, V.K.; Kumar, R.; Azim, A.; Malhotra, S.; Kumar, N.; Jain, R.; Sharma, N,K.; Tyagi, O.D.; Lawrie, S.J.; Errington, W.; Howarth, O.W.; Olsen, C.E.; Singh, S.K. \& Wengel, J. 1998. Polyphenols and alkaloids from Piper species. Phytochemistry 49: 1069-1078.

Payne, G.F.; Bringi, V.; Prince, C. \& Shuler, M.L. 1991. Immobilized plant cell. Pp. 179-223. In: G.F. Payne; V. Bringi; C. Prince \& M.L. Shuler (eds.). Plant Cell and Tissue Culture in Liquid Systems. Oxford, Oxford University Press.

Philip, V.J.; Joseph, D.; Triggs, G.S. \& Dickinson N.M. 1992. Micropropagation of black pepper (Piper nigrum Linn.) trough tip cultures. Plant Cell Reports 12: 41-44.

Silva, R.V.; Navickiene, H.M.D.; Kato, M.J.; Bolzani, V.; Méda, C.I.; Young, M.C.M. \& Furlan, M. 2002. Antifungal amides from Piper arboreum and Piper tuberculatum. Phytochemistry 59: 521-527.

Soniya, E.V. \& Das, M.R. 2002. In vitro micropropagation of Piper longum - an important medicinal plant. Plant Cell, Tissue and Organ Culture 70: 325-327.
Stals, H. \& Inzé D. 2001. When plant cells decide to divide. Trends in Plant Science 6: 359-364.

Smith, M.A.; Kobayashi, H.; Gawienowski, M. \& Briskin, D.P. 2002. An in vitro approach to investigate medicinal chemical synthesis by three herbal plants. Plant Cell, Tissue and Organ Culture 70: 105-111.

Szabados, L.; Mroginski, L.A. \& Roca, W.M. 1993. Suspensiones celulares: descripción, manipulación y aplicaciones. Pp. 174-210. In: W.M. Roca \& L.A. Mroginski (eds.). Cultivo de Tejidos en la Agricultura: Fundamentos y Aplicaciones. Cali, CIAT.

Teixeira, J.B.; Sondahl, M.R. \& Kirby, E.G. 1994. Somatic embryogenesis from immature inflorescences of oil palm. Plant Cell Reports 13: 247-250.

Vanisree, M.; Lee, C.Y.; Lo, S.F.; Nalawade, S.M.; Lin, C.Y. \& Tsay, H.S. 2004. Studies on the production of some important secondary metabolites from medicinal plants by tissue cultures. Botanical Bulletin of Academia Sinica 45: $1-22$.

Yusuf, A.; Thyagi, R.K. \& Malik, S.K. 2001. Somatic embryogenesis and plant regeneration from leaf segments of Piper colubrinum. Plant Cell, Tissue and Organ Culture 65: $255-258$. 